\title{
ANALISIS KASUS ATAS DUGAAN TERJADINYA INSIDER TRADING DALAM PERDAGANGAN SAHAM PT. PERUSAHAAN GAS NEGARA (PERSERO) TBK.
}

\author{
Dedi Indra Sari
}

\section{Abstrak}

This article is published as research result on actual case of insider trading in Jakarta Stock Exchange concerning state owned enterprise PT Perusahaan Gas Negara (persero). Under Law Number 8 year 1995 regarding Pasar Modal (Stock Exchange) article of 95 the due process must be conducted because the most factors fulfilled. In case any suspect on insider trading or another criminal conducts the role of stock exchange authority is mostly important. It will be effective in illicit suspicion on stock transaction any emiten and auto rejection can detect that by indicators: return or negative return, volatility, frequency transaction, volume transaction, domination of market members. The critical point of the author is directed to stock exchange authority that in step was not conducted real action to prevent crime conduct. The exception rule under Article 98 is not lawfully to prohibit or not doing investigation and in the author thought investigation must be conducted to sustain through prosecution.

Kata kunci: hukum ekonomi, pasar modal, analisis kasus, insider trading

\section{Pendahuluan}

\section{A. Latar Belakang}

Perkembangan pasar modal Indonesia telah membawa dampak signifikan terhadap perkembangan perekonomian dalam sektor perdagangan efek. Sebagai salah satu indikator perekonomian, pasar modal merupakan sub-industri keuangan yang mempunyai karakter spesifik dalam perdagangan sahamnya. Keterbukaan informasi menjadi signifikan bagi investor untuk memilih dan menempatkan investasi mereka pada portofolio efek yang ditawarkan dalam pasar perdana maupun pasar sekunder, sehingga pilihan investasinya pada salah satu portofolio efek dapat menghasilkan keuntungan. Karena keterbukaan informasi menjadi hal yang sangat fundamental bagi para investor, maka dalam setiap transaksi sekuritas, informasi tersebut 
akan dijadikan acuan bagi investor untuk mengambil keputusan guna menginvestasikan modalnya di pasar modal.'

Mengingat demikian kompleksnya kegiatan di pasar modal maka dibutuhkan suatu landasan hukum yang kokoh untuk lebih menjamin kepastian hukum bagi pihak-pihak yang terlibat dalam kegiatan di pasar modal termasuk juga melindungi kepentingan investor. Berlandaskan pemikiran tersebut maka pada tahun 1995 disahkan Undang-Undang Nomor 8 Tahun 1995 Tentang Pasar Modal (UUPM) dan mulai berlaku 1 Januari 1996 untuk mengganti undang-undang yang lama yang dianggap sudah tidak sesuai lagi untuk mengantisipasi kejahatan pasar modal.

UUPM memberikan kewenangan yang lebih besar kepada Badan Pengawas Pasar Modal (Bapepam) sebagai otoritas pasar modal untuk melaksanakan tugas pengawasan, pembinaan dan penegakan hukum. UUPM memberi kewenangan kepada Bapepam untuk melakukan pemeriksaan dan penyidikan atas pelanggaran yang dilakukan oleh para pelaku pelaku pasar modal, serta menjatuhkan sanksi. ${ }^{2}$

Salah satu kewenangan yang cukup fantastis diberikan kepada Bapepam oleh UUPM adalah kewenangan untuk bertindak selaku penyidik apabila menurutnya telah terjadi pelanggaran UUPM (dalam hal ini tindak pidana) yang membahayakan kepentingan pasar modal itu sendiri maupun kepentingan masyarakat. Bahkan Bapepam dapat bertindak sebagai penyelidik yang menurut ketentuan UUPM digunakan istilah Pemeriksa.

Adapun penulisan ini akan difokuskan pada studi kasus sebagai berikut, yaitu pada 8 Januari 2007 suatu transaksi yang tidak wajar atas saham PT. Perusahaan Gas Negara (Persero) Tbk. (PGAS) dimana dalam harga pembukaan perdagangan Rp.10.850,00 perlembar saham, dan pada penutupan perdagangan jatuh ke harga Rp.7.400,00 perlembar sahamnya (31,8\%). Kemudian pada tanggal 11 Januari 2007 transaksi harga perdagangan dibuka pada Rp.9.650,00 dan pada harga penutupan perdagangan jatuh kembali ke Rp.7.400,00 atau terjadi lagi penurunan $(23,3 \%)$. Pemicunya ternyata PGAS terlambat

1 Sofyan A. Djalil, Manipulation and Insider Trading, (Jakarta: Makalah disampaikan dalam Pendidikan dan Latihan Modul Capital Market Studies Program (CMSP) Bagi Profesi Penunjang Untuk Konsultan Hukum Pasar Modal, oleh Lembaga Manajemen Keuangan dan Akuntasi (LMKA) bekerja sama dengan Himpunan Konsultan Hukum Pasar Modal (HKHPM) Angkatan VI, 10-28 Juni 1996), hal. 1.

${ }^{2}$ M. Irsan Nasarudin dan Indra Surya, M. Irsan Nasarudin dan Indra Surya, "Aspek Hukum Pasar Modal Indonesia”, (Jakarta: Prenada Media, 2004), Sekapur Sirih, hal. 46. 
memberitahukan ke publik tentang penyelesaian proyek Pipanisasi South Sumatera-West Java (SSWJ), akibatnya terjadi panic selling yang melanda investor asing maupun lokal. ${ }^{3}$

Atas kejadian tersebut Bursa Efek Jakarta (BEJ) curiga ada sesuatu yang tidak benar dari transaksi tersebut sehingga BEJ mensuspend atau menghentikan sementara perdagangan saham tersebut pada tanggal 15 Januari 2007, suspensi dilakukan karena melihat penurunan saham PGAS yang sangat tajam hingga $23,3 \%$ dan melaporkannya kepada Bapepam selaku pengawas pasar modal. ${ }^{4}$

Terkait dengan kasus ini menarik untuk diketahui mengenai apa sebenarnya yang terjadi, apakah memang betul telah terjadi suatu kecurangan dan/atau kejahatan, dan bagaimana Bapepam bertindak inilah yang menjadi fokus penelitian ini.

\section{B. Pokok Permasalahan}

Berdasarkan latar belakang diatas maka penulis mengidentifikasikan masalah sebagai berikut :

1. Apa sajakah indikator yang dapat digunakan sebagai langkah awal pembuktian adanya insider trading?

2. Bagaimanakah peranan Bapepam dan Bursa Efek dalam hal terjadi tindak pidana dugaan insider trading dalam perdagangan saham PT. Perusahaan Gas Negara (Persero) Tbk.?

3. Bagaimanakah upaya dan langkah-langkah yang diambil Bapepam dalam rangka mengungkap kejahatan perdagangan insider trading PT. Perusahaan Gas Negara (Persero) Tbk.?

\section{Metode Penelitian}

Penelitian ini merupakan penelitian hukum normatif dengan studi kasus "dugaan insider trading pada PT. Perusahaan Gas Negara (Persero) Tbk." agar dapat diperoleh gambaran yang lebih jelas tentang penegakkan hukum di pasar modal oleh Bapepam sesuai dengan kekuasaan yang diberikan oleh UUPM.

3 Transaksi Saham PGN di Stop, <http://www.detikfinance.com/index.php/>, diakses tanggal 15 Maret 2007.

4 Bapepam: Pelaku Kasus PGN Mengarah ke Perseorangan, $<$ http://www.tempointeraktif.com/hg/ekbis/2007/02/05/brk,20070220-93778,id.html>, diakses tanggal 15 Maret 2007. 
Penelitian ini bertujuan untuk mengungkapkan kebenaran secara sistimatis, metodologis, dan konsisten. Dimana keberadaan suatu metodologi di dalam setiap penelitian dan pengembangan ilmu pengetahuan adalah merupakan suatu unsur yang mutlak dan harus ada. $^{5}$

Pengolahan dan analisa data yang digunakan dalam penelitian ini adalah analisa data secara kualitatif dengan mempergunakan dasardasar ilmu hukum. Sedangkan penulisan skripsi ini disajikan dalam bentuk yang bersifat deskriptif - analisis - preskriptif.

\section{Pembahasan}

\section{A. Tindak Pidana Pasar Modal}

Di dalam UUPM secara tegas membagi dua tindak pidana yang terjadi yaitu: pertama, tindak pidana yang sifatnya pelanggaran, dan kedua adalah tindak pidana yang bersifat kejahatan. Persamaan dari keduanya adalah sama-sama merupakan tindak pidana, sehingga dapat dikenakan sanksi pidana terhadap pihak yang melanggarnya, sedangkan perbedaannya terletak pada bobot kesalahannya serta beratnya sanksi pidana yang dapat dikenakan.

Tetapi pada penelitian ini akan difokuskan pada pembahasan mengenai kejahatan di pasar modal yaitu, kejahatan yang khas dilakukan oleh pelaku pasar modal dalam kegiatan pasar modal. Secara internasional, kasus-kasus kejahatan di pasar modal modusnya tidak jauh berbeda. Pemerintah Indonesia, melalui Bapepam berupaya keras untuk mengatasi dan mencegah tindak kejahatan di pasar modal Indonesia dengan berbagai cara, antara lain menertibkan dan membina pelaku pasar modal sebagai tindakan preventif, dan menuntaskan kejahatan di bidang pasar modal sebagai tindakan represif. ${ }^{6}$ Sanksi pidana bagi kejahatan ini jauh lebih berat dari pada pelanggaran, karena bobot kesalahannya memang lebih berat dari pelanggaran, dan dampak serta akibat yang ditimbulkan dari kejahatan ini sangat serius, dimana tidak hanya bersifat materil-individual (kebendaan dan

5 Soerjono Soekanto dan Sri Mamuji, "Penelitian Hukum Normatif", Cet.4, (Jakarta: PT. Raja Grafindo Persada, 1994), hal. 1.

${ }^{6}$ M. Irsan Nasarudin dan Indra Surya, Op. Cit., hal. 257. 
menyangkut pihak-pihak tertentu), tetapi juga mempunyai dampak psikologis terhadap pasar modal dan masyarakat. Langkah yang diambil oleh UUPM ini, dengan menetapkan sanksi pidana (hukuman) yang sangat berat adalah tepat. Hal tersebut dilakukan agar pelaku kejahatan di pasar modal ini menjadi jera, walaupun faktor hukuman bukanlah satu-satunya yang dapat mempengaruhi penegakan hukum di pasar modal. Faktor penting lainnya bagaimana mengaplikasikan dalam menjatuhkan hukumannya, serta kesungguhan aparat penegak hukumn, dan masih banyak lagi.

Kejahatan pasar modal dapat dibagi kedalam tiga kategori menurut berat ancaman pidananya, yaitu:

1. Kejahatan dengan ancaman pidana kurungan paling lama 3 tahun dan denda maksimal Rp. 5 miliar. Kejahatan yang terkena ancaman ini adalah pelanggaran yang dilakukan oleh Emiten atau perusahaan publik yang tidak menyampaikan Pernyataan Pendaftaran kepada Bapepam dalam rangka penawaran umum yang dilakukan, kemudian juga terhadap pihak yang dengan sengaja bertujuan menipu atau menyesatkan Bapepam, dengan cara menghilangkan, menghapus, memusnahkan, mengubah catatan perizinan, persetujuan atau pendaftaran yang dimiliki. ${ }^{8}$

2. Kejahatan dengan ancaman pidana kurungan paling lama 5 tahun dan denda maksimal Rp 5 milar. Kejahatan yang dimaksud adalah pelanggaran terhadap kewajiban memiliki izin (teknis administrasi) dari Bapepam, bagi pihak-pihak yang akan melakukan kegiatan di pasar modal, yaitu izin sebagai Bursa Efek (Pasal 6), LKP dan LPP (Pasal 13), Reksadana (Pasal 18), Perusahaan Efek (Pasal 30), Penasihat Investasi (Pasal 34), Kustodian (Pasal 43), BAE (Pasal 48), Wali Amanat (Pasal 50), dan sebagai profesi penunjang (Pasal 64). ${ }^{9}$

3. Kejahatan dengan ancaman pidana kurungan paling lama 10 tahun dan denda maksimal Rp 15 miliar. Kejahatan dalam kelompok ini adalah yang paling berat dan sangat diharamkan di pasar modal, yaitu melakukan penipuan (sebagaimana rumusan pasal 90),

7 Indonesia, Undang-Undang Tentang Pasar Modal, UU No. 8. LN No. 64 Tahun 1995. TLN No. 3608, Pasal 73 jo. Pasal 106 ayat (2) jo. Pasal 110 ayat (2).

${ }^{8}$ Ibid., Pasal 107 jo. Pasal 110 ayat (2).

${ }^{9}$ Ibid., Pasal 103 ayat (1) jo. Pasal 110 ayat (2). 
menciptakan gambaran semu mengenai kegiatan perdagangan atau keadaan pasar (Pasal 91), melakukan stabilisasi harga (Pasal 92), membuat pernyataan menyesatkan (Pasal 93), insider trading (Pasal 95), larangan bagi orang dalam (Pasal 96), memperoleh informasi orang dalam secara melawan hukum (Pasal 97), serta larangan bagi perusahaan efek yang termasuk orang dalam untuk melakukan transaksi atas efek Emiten tersebut (Pasal 98), juga menyalahi ketentuan mengenai pihak yang dapat mengajukan pernyataan pendaftaran (Pasal 70). ${ }^{10}$

Ketiga golongan inilah yang termasuk sebagai tindak pidana yang merupakan kejahatan sebagaimana ditetapkan oleh UUPM dalam Pasal 110 ayat (2).

Diseluruh pasar modal dunia, skandal dan kasus kejahatan telah menjadi bagian dari kehidupan pasar modal. Kejahatan tersebut dikenal "praktek curang" yang sering dilakukan oleh pelaku pasar. Hal ini terjadi karena kelicikan, ketamakan, dan keserakahan merupakan elemen utama yang menggoda pelaku pasar. Oleh sebab itu, kepentingan penegakan hukum dengan penegakan etika profesional harus dapat sejalan. ${ }^{11}$ UUPM mengaturnya dengan memberikan sanksi yang sangat berat, dan termasuk dalam kategori tiga dari sisi sanksi pidananya sebagaimana telah disebutkan di atas. Pengenaan sanksi yang berat ini sangat tepat, mengingat praktek curang merupakan praktek yang tidak etis dan tidak bermoral untuk dilakukan di pasar modal.

Pada prakteknya terdapat jenis-jenis tindak pidana yang dikenal di dunia pasar modal, yaitu penipuan (fraud) dan manipulasi pasar (market manipulation). ${ }^{12}$ Pada penelitian ini tidak akan membahas mengenai tindak pidana penipuan tetapi memfokuskan pada tindak pidana manipulasi pasar.

Dalam praktek perdagangan efek internasional dikenal beberapa kegiatan yang dapat digolongkan sebagai manipulasi pasar, yaitu: ${ }^{13}$

1. Marking the close;

${ }^{10}$ Ibid., Pasal 104 dan 106 ayat (1) jo. Pasal 110 ayat (2).

"Indra Safitri, "Kejahatan Di Pasar Modal", (Jakarta: Go Global Book Publishing Division Safitri \& Co, 1998), hal. 203.

${ }^{12}$ M. Irsan Nasarudin dan Indra Surya, Op. Cit., hal. 260.

${ }^{13}$ Ibid., hal. 265. 
2. Painting the tape;

3. Pembentukan harga berkaitan dengan merger, konsolidasi, atau akuisisi;

4. Cornering the market;

5. Pools;

6. Wash Sale;

7. Insider trading;

Dalam penulisan ini akan memfokuskan pada kegiatan manipulasi pasar dengan bentuk tindak pidana insider trading.

\section{B. Insider Trading}

\section{Pengertian Insider Trading}

Insider TraAting atau perdagangan dengan informasi orang dalam adalah orang dalam atau pihak-pihak yang mempunyai hubungan dapat juga disebut pihak terafiliasi dengan Emiten, dimana mereka dimungkinkan untuk memiliki informasi tentang kejadian atau peristiwa penting mengenai kinerja Emiten yang dapat mempengaruhi harga saham Emiten tersebut di Bursa Efek, dan belum diumumkan kepada publik serta masih menjadi rahasia perusahaan. Informasi material tersebut masih rahasia, digunakan oleh pihak insider (orang dalam) untuk melakukan transaksi atas efek Emiten tersebut, dengan maksud untuk memperoleh keuntungan bagi dirinya sendiri.

Kemungkinan terjadinya perdagangan dengan menggunakan informasi orang dalam, dapat dideteksi dari ada atau tidaknya orang dalam yang melakukan transaksi atas efek perusahaan dimana yang bersangkutan menjadi orang dalam. Selain itu, dapat dideteksi dari adanya peningkatan harga dan volume perdagangan efek sebelum diumumkannya informasi material kepada publik, dan terjadinya peningkatan atau penurunan harga dan volume perdagangan yang tidak wajar. Perdagangan orang dalam mengandung beberapa unsur, yaitu:

1. Adanya perdagangan efek;

2. Dilakukan oleh orang-orang dalam perusahaan;

3. Adanya inside information;

4. Informasi itu belum diungkap dan terbuka untuk umum;

5. Perdagangan tersebut dimotivasi oleh informasi itu:

6. Tujuan untuk mendapatkan keuntungan. 
Perdagangan orang dalam atau Insider trading, baik langsung maupun tidak langsung dapat digolongkan sebagai perdagangan yang dilakukan dengan menggunakan informasi yang masih bersifat rahasia belum terbuka untuk umum. Bagi perusahaan publik, ada kewajiban untuk mengumumkan kepada publik tentang peristiwa ataupun kejadian-kejadian penting atas perusahaan tersebut paling lambat pada akhir hari kerja kedua agar publik mendapatkan informasi penting tersebut secara bersama-sama, sehingga investor dapat membuat pertimbanganpertimbangan apakah akan menjual ataupun membeli efek Emiten tersebut dalam rangka investasi yang dilakukannya. Pihak insider yang memberitahukan informasi penting yang belum terbuka untuk umum tersebut kepada pihak lain, dapat disebut telah membocorkan rahasia perusahaan. ${ }^{14}$

Pembuktian kasus insider trading cenderung sulit, karena mempunyai modus yang canggih dan kompleks, maka Bapepam dituntut untuk mampu menuntaskan perkara perdagangan orang dalam secara meyakinkan. ${ }^{15}$

\section{Kewajiban Disclosure (Keterbukaan Informasi)}

Disclosure merupakan suatu hal yang sangat mutlak dalam pasar modal, berbeda dengan sektor perbankan dimana prinsip kerahasiaan bank adalah hal yang mutlak untuk ditaati, sektor pasar modal menerapkan hal sebaliknya, disclosure atau keterbukaan informasi adalah mutlak. ${ }^{16}$ Transparansi dalam pasar modal berarti keharusan, hal ini secara tegas diatur dalam Pasal 1 angka 25 UUPM.

Informasi adalah komoditi yang sangat penting dalam suatu Bursa Efek, oleh karena itu informasi mengenai suatu peristiwa yang terjadi atas suatu Emiten yang sahamnya diperdagangkan di Bursa Efek tidak boleh diketahui hanya oleh satu pihak secara eksklusif. Begitu pentingnya informasi ini, UUPM menetapkan bahwa paling lambat hari kedua setelah kejadian penting itu terjadi harus sudah diumumkan kepada publik, hal ini terkait dengan ketentuan bahwa setiap perusahaan publik mempunyai

\footnotetext{
${ }^{14} \mathrm{Jbid}$, hal. 269.

${ }^{15}$ Ihid. hal. 270 .

It' Ibid., hal. 225.
} 
kewajiban akan keterbukaan informasi (disclosure) atas segala kejadian ataupun informasi yang bersifat material, yang dapat mempengaruhi harga saham Emiten tersebut di Bursa Efek.

Informasi yang bersifat material ini apabila belum diumumkan kepada publik berarti masih bersifat rahasia dan tidak boleh dimanfaatkan untuk melakukan transaksi oleh pihak yang termasuk orang dalam Emiten sesuai UUPM, dan tidak boleh dibocorkan kepada pihak tertentu, diluar orang dalam tersebut. Apabila informasi ini dibocorkan kepada pihak tertentu, ataupun digunakan oleh orang dalam sendiri untuk melakukan transaksi, maka investor lain yang belum mendapatkan informasi tersebut akan mengalami kerugian dan ketidak adilan serta perdagangannya disebut sebagai perdagangan orang dalam atau "insider trading".

Bagi investor di Bursa Efek, informasi sangatlah penting, karena dapat digunakan sebagai pertimbangan untuk memutuskan apakah akan melakukan investasi (membeli) atau melepaskan (menjual). Oleh sebab itu, pihak yang mengetahui terlebih dahulu atas informasi penting suatu Emiten akan melakukan tindakan tertentu, misalnya menjual (pada harga yang lebih tinggi) apabila informasi atas kejadian yang dia ketahui tersebut akan menurunkan harga saham, dan membeli (pada harga yang lebih rendah) apabila kejadian tersebut akan menaikan harga saham. Dengan demikian, prinsipnya bahwa setiap orang harus mendapatkan informasi penting tentang Emiten dalam waktu yang bersamaan, hal ini dimaksudkan untuk menghindarkan kemungkinan seseorang mendapatkan informasi dengan merugikan orang lain atau menguntungkan dirinya sendiri.

Transparansi atau keterbukaan informasi ini merupakan suatu bentuk perlindungan hukum kepada investor, dari segi substansial transparansi membuat publik untuk mendapatkan akses informasi penting yang berkaitan dengan perusahaan. Suatu pasar modal dikatakan fair dan efisien apabila semua pemodal memperoleh informasi dalam waktu yang bersamaan disertai kualitas informasi yang sama (equal treatment) dalam akses informasi. Dari sisi yuridis, transparansi merupakan jaminan bagi hak publik untuk terus mendapatkan akses penting, dengan sanksi untuk hambatan atau kelalaian yang dilakukan perusahaan. Pengenaan sanksi yang termuat dalam UUPM serta penegakan hukum atas setiap pelanggaran terhadap ketentuan mengenai keterbukaan atau transparansi ini menjadikan pemegang saham 
atau investor terlindungi secara hukum dari praktik-praktik manipulasi dalam perusahaan publik. ${ }^{17}$

\section{Sanksi dan Latar Belakang Pelarangannya}

Perdagangan dengan informasi orang dalam (Insider trading) adalah tindakan berbahaya dan merugikan bagi pasar modal, insider trading itu sendiri dapat diartikan juga dengan "kolusi" yang memang harus diberantas karena sangat merugikan dan menimbulkan ketidak adilan bagi para pelaku pasar modal. Sedangkan yang menjadi latar belakang pelarangannya itu sendiri karena tindakan tersebut dapat menimbulkan bahaya bagi: ${ }^{18}$

a. Mekanisme Pasar yang Fair dan Efisien;

b. Berdampak Negatif Bagi Emiten;

c. Kerugian Materiel Investor;

d. Kerahasiaan Milik Perusahaan.

Oleh karena itu jelas, kenapa insider trading itu dilarang, sebab menimbulkan kerugian dari pada mendatangkan keuntungan, kecuali bagi para pelaku itu sendiri. Sudah sepatutnya insider trading dilarang, dan pelakunya dikenai sanksi pidana sebab merugikan banyak pihak.

\section{Syarat Terjadinya Insider Trading}

Suatu perdagangan dapat dikatakan termasuk insider trading atau perdagangan dengan informasi orang dalam haruslah memenuhi syarat-syarat atau ketentuan tentang insider trading, syarat-syarat insider trading yang dimaksudkan yaitu adanya:

1. Pihak-pihak yang Termasuk Insider (Orang Dalam)

UUPM melalui penjelasan pasal 95 memberi arti kepada insider (orang dalam) sebagai pihak-pihak yang tergolong atau dapat digolongkan sebagai berikut:

i. Komisaris, direktur, dan atau pegawai perusahaan terbuka;

${ }^{17}$ M. Irsan Nasarudin dan Indra Surya, Op. Cit., hal. 227.

${ }^{18}$ Munir Fuady, "Pasar Modal Modern (Tinjauan Hukum)", (Bandung: PT. Citra Aditya Bakti, 1996), hal. 168-169. 
ii. Pemegang saham utama Emiten atau Perusahaan Terbuka;

iii. Perorangan yang mempunyai hubungan Dengan emiten;

iv. Pihak sebagai mantan insider (orang dalam).

Terhadap pihak-pihak tersebut terdapat pengecualian yaitu Komisaris, Direktur, Pegawai Emiten ataupun Pemegang Saham Utama Emiten, yang sudah tidak lagi menjadi insider (orang dalam) seperti yang dimaksud dalam huruf a, b, c diatas, tetapi belum melampaui jangka waktu 6 (enam) bulan. Artinya bila seorang direktur atau komisaris suatu Emiten atau perusahaan terbuka berhenti atau mengundurkan diri misalnya pada tanggal 1 Januari 2000 maka sampai dengan tanggal 30 Juni 2000 masih dianggap sebagai insider (orang dalam), dan setelah tanggal 1 Juli 2000 dia tidak lagi termasuk orang dalam". ${ }^{19}$

2. Inside Information (Informasi Orang Dalam)

Informasi orang dalam (inside information) adalah informasi penting termasuk fakta material yang dimiliki oleh orang dalam yang belum tersedia untuk publik, sedangkan informasi atau fakta material yang dimaksudkan ialah informasi atau fakta penting dan relevan mengenai peristiwa, kejadian atau fakta yang dapat mempengaruhi harga efek pada bursa dan atau keputusan pemodal/calon pemodal, atau pihak lain yang berkepentingan dengan informasi atau fakta material tersebut.

Pengertian lain adalah segala sesuatu kejadian dalam perusahaan (corporate affairs) yang belum terbuka untuk umum, di mana pihak officers dari perusahaan yang bersangkutan telah terlebih dahulu mengetahui informasi tersebut, misalnya jika perusahaan akan melakukan akuisisi, atau earnings report yang terakhir sangat berbeda dengan informasi yang telah lebih dahulu direlease. ${ }^{20}$ Informasi tersebut tidak dibenarkan untuk menjadi dasar pertimbangan dalam hal melakukan perdagangan.

${ }^{19}$ Indonesia, Undang-undang Tentang Pasar Modal, UU No. 8 Tahun 1995. Pasal 95 (Penjelasan).

${ }^{20}$ Jack P. Friedman, "Dictionary of Business Terms". (New York, USA: Baron's Educational Series, Inc., 1987), hal. 288. 
Mengenai jenis-jenis informasi atau fakta material yang harus diumumkan segera selambat-lambatnya di akhir hari kerja kedua kepada masyarakat dan diberitahukan kepada Bapepam, diberikan contoh-contoh informasi yang dimaksudkan dalam Peraturan No. X.K.1. tentang Keterbukaan Informasi yang Harus Segera Diumumkan Kepada Publik, menyebutkan peristiwa, informasi, atau fakta material yang diperkirakan dapat mempengaruhi harga efek atau keputusan investasi, antara lain: ${ }^{21}$

a. Penggabungan usaha, pembelian saham, peleburan usaha, atau pembentukan usaha patungan;

b. Pemecahan saham atau pembagian deviden saham;

c. Pendapatan dari deviden yang luar biasa sifatnya;

d. Perolehan atau kehilangan kontrak penting;

e. Produk atau penemuan baru yang berarti;

f. Perubahan dalam pengendalian atau perubahan penting dalam manajemen;

g. Pengumuman pembelian kembali atau pembayaran efek yang bersifat utang;

h. Penjualan tambahan efek kepada masyarakat atau secara terbatas yang meterial jumlahnya;

i. Pembelian atau kerugian penjualan aktiva yang material;

j. jPerselisihan tenaga kerja yang relatif penting;

k. Tuntutan hukum yang penting terhadap perusahaan dan atau direktur dan komisaris perusahaan;

1. Pengajuan tawaran untuk pembelian efek perusahaan lain;

m. Penggantian akuntan yang mengaudit perusahaan;

n. Penggantian wali amanat;

o. Perubahan tahun fiskal perusahaan.

Jenis-jenis informasi diatas merupakan sebagian informasi yang dijadikan contoh, selain itu masih banyak jenis informasi material seperti kebakaran, kalah dalam permainan valas atau sejenisnya dan lain-lain, yang kesemuanya adalah berupa informasi atau fakta material yang harus segera diumumkan kepada publik untuk mencegah ketidakadilan bagi para pelaku bursa, sebab informasi merupakan komoditi

${ }^{21}$ M. Irsan Nasarudin dan Indra Surya, Op. Cit., hal. 152. 
penting bagi investor dalam mengambil keputusan berkaitan dengan investasi yang dilakukannya.

3. Trading (Terjadinya Perdagangan)

Syarat lainnya setelah adanya pihak insider (orang dalam), memiliki inside information (informasi bersifat material yang belum tersedia untuk umum), maka syarat ketiga adalah terjadinya trading (perdagangan). Perdagangan yang dimaksud adalah transaksi, baik jual maupun beli yang dilakukan oleh insider (orang dalam) atau pihak yang mendapat informasi dari insider (orang dalam) atas efek Emiten yang dimaksudkan. Bila trading (perdagangan) tidak dilakukan atau tidak terjadi, maka belum terpenuhi syarat untuk dapat disebut sebagai insider trading.

Di dalam UUPM pasal 95, pasal 96 dan pasal 97 yang mengatur tentang tindak pidana pasar modal (tetapi dalam hal ini Bapepam dapat membuat pengecualiannya, vide pasal 99) telah mengatur dengan tegas tentang trading yang dilarang untuk dilakukan. Delik insider trading baru dapat dikatakan sempurna bila adanya pihak yang tergolong insider, memiliki informasi material yang masih rahasia, kemudian insider itu melakukan transaksi atas efek tersebut, barulah dapat dikatakan terjadi insider trading sehingga berdasarkan fakta tersebut dapat mulai dilakukan tindakan penyidikan berkaitan dengan tindak pidana yang diatur dalam UUPM pasal 95.

\section{Indikator Terjadinya Insider Trading ${ }^{22}$}

\section{a. Return or Negative Return}

Tujuan melakukan insider trading adalah untuk memperoleh keuntungan yang tinggi (abnormal return) lebih dari biasanya. Perolehan keuntungan abnormal return berindikasi kuat disebabkan oleh insider trading. Untuk menelisik perolehan keuntungan yang lebih tinggi maka return dapat dijadikan salah satu indikator terhadap adanya dugaan insider trading.

${ }^{22}$ Arman Nefi, "Return, Volatilitas, Nilai Transaksi, dan Dominasi Anggota Bursa Di Seputar Dugaan Insider Trading", (Tesis Magister Manajemen Fakultas Ekonomi, Universitas Indonesia, Depok, 2005), hal. 33-34. 


\section{b. Volatilitas Return}

Seperti sudah disinggung sebelumnya, bahwa dalam kegiatan perdagangan, terjadinya insider trading diindikasikan dengan adanya volatilitas yaitu suatu kecenderungan harga untuk berubah secara tak terduga. Ada dua tipe volatilitas yaitu fundamental volatillity dan transitory volatility. Fundamental volatility disebabkan oleh perubahan yang tak diantisipasi pada nilai instrumen, dan transitory volatility disebabkan oleh aktivitas perdagangan oleh pedagang yang tak diketahui.

\section{c. Nilai Transaksi}

Nilai transaksi perdagangan saham akan terlihat sangat berbeda, apabila transaksi tersebut diduga mengalami insider trading, akan terdapat nilai transaksi yang sangat besar atau menurun sangat drastis dalam jangka waktu tertentu akibat adanya informasi material yang belum di ungkap ke publik, tetapi digunakan oleh para insider. Dengan demikian nilai transaksi sangat penting untuk dijadikan sebagia salah satu indikator adanya dugaan insider trading.

\section{d. Dominasi Anggota Bursa}

Dominasi anggota bursa dapat dijadikan sebagai salah satu indikasi terjadinya insider trading, karena akan terlihat pola-pola atau kebiasaan-kebiasaan anggota bursa dalam bertransaksi. Apakah suatu anggota bursa sangat dominan dalam melakukan transaksi suatu saham jika dibandingkan dengan transaksi anggota bursa yang lain. Walaupun para insider kemungkinan besar akan memecah atau mendistribusikan pesanan transaksinya pada beberapa anggota bursa, akan dapat terlihat dari kebiasaan anggot bursa bertransaksi pada perdagangan yang normal. 


\section{Analisa}

A. Analisis Praktik Insider Trading Dalam Perdagangan Saham PT. Perusahaan Gas Negara (Persero) Tbk. Di Bursa Efek Jakarta (BEJ)

\section{Indikasi Adanya Pelanggaran Pasal 95 UU No.8 Tahun 1995}

Pasal 95 UUPM jelas sekali menetapkan bahwa, orang dalam dari suatu Emiten yang memiliki informasi orang dalam (inside information), dilarang untuk melakukan transaksi atas saham Emiten tersebut. Dalam kasus ini, Bapepam-LK telah menemukan titik terang terhadap kasus turunnya harga saham PGN, hal ini diperoleh setelah PPNS Bapepam-LK memeriksa direksi PGN dan beberapa manajemen PGN. Hasilnya, dugaan adanya insider trading semakin menguat. Menurut Wahyu Hidayat (Kepala Biro Pemeriksaan dan Penyidikan Bapepam-LK) adanya dugaan insider trading setelah dia mendapat laporan dari Biro Transaksi Lembaga Efek (TLE) Bapepam-LK. Bahwa ketiga penasehat keuangan Pemerintah (financial advisor) dalam proses divestasi aktif melakukan transaksi atas saham PGN di BEJ, jelas memberikan indikasi bahwa mereka telah melakukan insider trading. Sebagai penasehat keuangan, mereka termasuk orang dalam PGN. Sedangkan mengenai inside information, jelas mereka ikut serta secara aktif dalam setiap perundingan Menneg BUMN dengan investor strategis. Mereka tentu mengetahui tentang bagaimana rencana tender offer PGN, siapa saja yang berminat, berapa besar saham yang akan dilepas, dan juga harga dari setiap sahamnya yang akan dilepas kepada investor. Itu semua merupakan inside information yang belum diumumkan kepada publik, sehingga masih bersifat rahasia perusahaan.

\section{Terpenuhinya Syarat dan unsur-unsur Tindak Pidana Insider Trading Sesuai Dengan Ketentuan Pasal 95 UU No.8 Tahun 1995}

Dari indikasi yang ada, dihubungkan dengan ketentuan pasal 95 UUPM, maka dapat disimpulkan bahwa unsur-unsur pasal 95 telah terpenuhi. Hal ini dapat dilihat dari masing-masing unsur pasal 95 tersebut. 
Unsur pertama, adalah adanya orang dalam. Dikaitkan dengan kasus PGN, maka para penasehat keuangan Pemerintah dan PGN, yaitu PT. Danareksa Sekuritas, PT. Bahana Sekuritas, dan CSLA telah memenuhi unsur orang dalam yang merupakan unsur pertama dari pasal 95 tersebut. Para penasehat keuangan tersebut termasuk orang dalam karena adanya hubungan kerja atau usaha dengan pihak Emiten (sebagai penasehat keuangan) berdasarkan pasal 95 UU No.8 Tahun 1995 beserta penjelasannya.

Unsur kedua, yaitu memiliki inside information (informasi orang dalam) yang belum tersedia untuk publik atau diumumkan. Dalam kasus PGN, unsur ini terpenuhi dengan adanya informasi yang masih bersifat rahasia dan belum diumumkan kepada publik, yaitu bahwa sebagai penasehat keuangan yang ikut aktif dalam proses divestasi ini, pasti mengetahui berapa banyak saham yang akan dilepas, berapa harga setiap lembar sahamnya dan informasi lainnya yang dapat mempengaruhi fiarga saham PGN di BEJ.

Unsur yang ketiga, adalah terjadinya atau dilakukannya transaksi oleh orang dalam tersebut. Unsur ini terpenuhi dengan terbuktinya bahwa ketiga penasehat keuangan tersebut, secara aktif melakukan transaksi atas saham PGN berdasarkan data transaksi dari BEJ yang diperoleh Bapepam-LK. Dalam data transaksi, tercatat masing-masing penasehat keuangan melakukan transaksi dalam kurun waktu yang sangat singkat.

Dengan terpenuhinya semua unsur-unsur yang ada dalam pasal 95 UU No.8 Tahun 1995, maka kepada mereka dapat disangka telah melakukan praktik "insider trading", dan oleh karenanya dapat dilakukan tindakan penyidikan, sebagai langkah awal dalam melakukan penuntutan atas tindak pidana yang dilakukan oleh pelaku. Apabila mereka di dalam pemeriksaan persidangan di pengadilan terbukti secara sah bersalah, maka kepada mereka dapat dikenakan sanksi pidana, sesuai dengan yang tercantum dalam pasal 104 UUPM yaitu penjara maksimum 10 tahun dan denda maksimum 15 miliar rupiah. 
B. Analisis Indikator Insider Trading di Bursa Terhadap Transaksi Saham PT. Perusahaan Gas Negara (Persero) Tbk.

\section{Negative Return Transaksi Saham PT. Perusahaan Gas Negara (Persero) Tbk.}

Indikasi negative return dugaan insider trading terhadap transaksi saham PGN dalam proses divestasi saham pemerintah sebesar 5,1\% sudah terlihat pada tanggal 18 Desember 2006. Harga saham sengaja diturunkan terlebih dari Rp.13.800,00 menjadi Rp.11.300,00. Indikasi kesengajaan untuk menurunkan harga saham tersebut untuk memberikan keuntungan pada pihak tertentu (back door profit). Kala itu, 15 Desember 2006 pemerintah melepas $5,31 \%$ atau 185.802 .000 lembar saham dengan harga Rp.11.350,00 per lembar, pemerintah mendapat untung (premium) Rp.50,00 per lembar saham atau 0,44\% dari harga penutupan tanggal 13 Desember 2006 yaitu Rp.11.300,00. Dengan pola membentuk harga lebih rendah untuk acuan divestasi $5,1 \%$ saham pemerintah sebagaimana diatur dalam Pasal 91 dan 92 UUPM, menunjukkan indikasi kuat terjadinya manipulasi harga, dengan terlihatnya unsur pemicu dan pembentuk harga atas permintaan pihak-pihak tertentu melalui sekuritas yang juga menjadi underwriter proses divestasi. Informasi tersebut disembunyikan yang harusnya di rilis kepada publik, yang bertentangan dengan prinsip utama dari perusahaan terbuka.

Dari keterangan tersebut di atas, maka pihak-pihak yang tergolong sebagai insider (orang dalam) menjadi jelas, bukan saja pihak insider tetapi juga termasuk pihak di luar emiten yang mempunyai hubungan kerja atau usaha dengan emiten ataupun tidak ada hubungan kerja tetapi memperoleh informasi yang bersifat material tersebut dari insider.

\section{Volatilitas Return Transaksi Saham PT. Perusahaan Gas Negara (Persero) Tbk.}

Pola 'penggorengan' bursa atas saham PGAS yang dilakukan merupakan unsur kesengajaan yang dilakukan oleh para pihak dengan tujuan untuk mendapatkan keuntungan. Harga di bentuk ke level lebih rendah oleh broker jual (seller inisiator) pada saat perdagangan baru dibuka dengan volume besar, diantaranya sekuritas underwriter yang memicu harga ke kisaran rendah. Pola volatilitas return dapat diketahui sejak tanggal 23 Agustus 2006, 
dimana harga saham PGAS konsisten mengalami penurunan di saat sentimen bursa tengah menaik, bersamaan dengan tersebarnya informasi publik tentang kesepakatan Pemerintah dan DPR atas proses divestasi 5,1\% saham PGAS.

Indikasi tersebut merupakan manipulasi harga (mark-down) yang dimaksudkan untuk membentuk acuan harga divestasi menjadi lebih rendah melalui transaksi bursa. Transaksi saham PGAS menjadi tidak terduga dengan mengalami penurunan di saat sentimen bursa sedang naik.

\section{Nilai Transaksi Saham PT. Perusahaan Gas Negara (Persero) Tbk.}

Ketika mekanisme tick price di bursa saham telah 'terdorong' membentuk harga konsisten ke bawah (10 tick), sekuritas underwriter lainnya (Bahana Sekuritas) menjadi tempat kejadian perkara atas pola transaksi untuk membentuk harga di akhir sesi perdagangan dengan 1 lot transaksi jual saja.

'Penggorengan' harga saham PGAS ke level lebih rendah, pada penutupan bursa pada tanggal 13 Desember 2006 pada level Rp.11.300,00, dan tidak di informasikan kepada publik, yang terjadi pada saat sentimen bursa sedang naik, lalu kemudian melepas/menjual saham di harga tertinggi, yaitu Rp.11.700,00 Rp.11950,00 sudah dapat dikategorikan perbuatan insider trading, dan sudah melanggar ketentuan UUPM.

\section{Dominasi Anggota Bursa dalam Transaksi Saham PT. Perusahaan Gas Negara (Persero) Tbk.}

Pola yang sangat terlihat sekali adalah pola yang dilakukan oleh anggota bursa pada pembukaan awal transaksi bursa saham dengan mendominasi pembentuk harga saham ke level lebih rendah terhadap saham PGAS. Puncaknya terjadi pada tanggal 12 Januari 2007 terjadi panic selling yang melanda investor asing maupun lokal, manajemen PGN telah menyalahi aturan mengenai penyampaian informasi berkaitan dengan tertundanya jadwal komersialisasi proyek pipanisasi South Sumatera - West Java (SSWJ) sehingga harga saham emiten berkode PGAS itu hanya dalam satu hari, turun 23\% ke harga Rp.7.400,00.

Berdasarkan data Bursa Efek Jakarta, terdapat tiga sekuritas asing yang aktif melepas saham berkode PGAS pada tanggal 12 Januari 2007 yaitu Macquaire Securities yang melepas 57,23 juta 
saham, Deutche Securities melepas 17,19 juta saham dan CSLA Securities melepas 14,7 juta saham. ${ }^{23}$ Akibatnya otoritas Bursa Efek Jakarta memutuskan untuk menghentikan sementara (suspend) perdagangan saham PGAS mulai sesi I, Senin 15 Januari 2007 yang diumumkan langsung ke para pialang di lantai bursa.

Pada kasus dugaan praktik insider trading dalam perdagangan saham PGN, Bapepam-LK juga telah menggunakan kewenangannya untuk melakukan pemeriksaan terhadap semua pihak yang termasuk sebagai insider (orang dalam). Dalam pemeriksaan, para penasehat keuangan pemerintah yaitu Para Direksi Danareksa Sekuritas, Bahana Sekuritas, dan CLSA mereka semua membantah telah melakukan praktik insider trading, dengan argumen yang didasarkan pada adanya pengecualian yang dibenarkan oleh pasal 98 UU Pasar Modal.

C. Analisis Terhadap Pelaksanaan Kewenangan Pemeriksaan Dan Penyidikan Dalam Kasus Dugaan Tindak Pidana Insider Trading Perdagangan Saham PT. Perusahaan Gas Negara (Persero) Tbk. oleh Bapepam

Tujuan dari pelaksanaan pemeriksaan oleh Bapepam sebetulnya tidak berbeda jauh dengan penyelidikan yang dilakukan oleh Polisi. Penyelidikan oleh Polisi adalah khusus untuk tindak pidana, sedangkan pemeriksaan oleh Bapepam adalah untuk semua bentuk pelanggaran UUPM, termasuk pelanggaran administratif maupun kejahatan dalam bidang pasar modal seperti insider trading. Akan tetapi tujuan utamanya adalah untuk mencari dan menemukan bukti awal serta menemukan peristiwa pelanggaran pidananya.

Apabila terjadi pelanggaran secara administratif, maka seluruh temuan berupa data, informasi, bahan dan atau keterangan lain yang dikumpulkan dalam pemeriksaan tersebut, dapat digunakan sebagai dasar oleh Bapepam untuk menetapkan sanksi administratif, sedangkan dalam hal telah terjadi pelanggaran yang bersifat pidana, maka Bapepam dapat menetapkan untuk meneruskan ketahap berikutnya yaitu penyidikan, dan seluruh 
temuan dalam pemeriksaan tadi dapat digunakan sebagai bukti awal untuk pelaksanaan penyidikan. ${ }^{24}$

Pada kasus dugaan praktik insider trading dalam perdagangan saham PGN, Bapepam-LK telah menggunakan kewenangannya untuk melakukan pemeriksaan terhadap semua pihak yang termasuk sebagai insider (orang dalam). Dalam pemeriksaan, para penasehat keuangan Pemerintah yaitu Para Direksi PT. Danareksa Sekuritas, PT. Bahana Sekuritas, dan CLSA securities membantah telah melakukan praktik insider trading, dengan argumen yang didasarkan pada adanya pengecualian yang dibenarkan oleh pasal 98 UUPM. Akan tetapi penyelesaiannya pada kasus ini belum tuntas, karena pihak Bapepam-LK tidak mendapatkan bukti bahwa telah terjadi insider trading.

Seharusnya berdasarkan bukti awal yang didapat dalam pemeriksaan yaitu, bahwa ketiga penasehat keuangan Pemerintah PT. Danareksa Sekuritas, PT. Bahana Sekuritas, dan CSLA adalah nyata-nyata berkedudukan sebagai orang dalam PGN karena ada hubungan kerja sebagai penasihat keuangan Pemerintah. Mereka ikut dalam proses negosiasi dengan pihak investor strategis yang berminat, sehingga mendapatkan informasi yang bersifat material, belum terbuka untuk publik dan dapat mempengaruhi harga saham Emiten tersebut dibursa. Seperti jumlah saham yang akan dilepas, dan diinginkan oleh investor, juga berapa harga setiap lembar sahamnya. Peristiwa pidananya sendiri adalah, bahwa mereka aktif melakukan perdagangan saham PGN di Bursa Efek, berarti syarat terjadinya insider trading ataupun unsur-unsur pasal 95 telah terpenuhi.

Terpenuhinya unsur-unsur pasal 95 (penjelasannya) UUPM disebabkan karena pasal 95 (penjelasannya) UUPM memberikan penekanan kepada orang dalam dilarang melakukan transaksi, bukan didasarkan kepada informasi yang dimiliki orang dalam tersebut, apakah digunakan atau tidak dalam melakukan transaksi atas saham Emiten tersebut, juga atas pertimbangan bahwa kedudukan orang dalam seharusnya mendahulukan kepentingan Emiten, Perusahaan Publik atau pemegang saham secara keseluruhan, termasuk di dalamnya untuk tidak menggunakan informasi orang dalam untuk kepentingan diri sendiri atau pihak

${ }^{24}$ Indonesia, Op. Cit., Pasal 100 ayat (2) dan Penjelasan. 
lain. Berdasarkan hal tersebut, Bapepam dapat menetapkan dimulainya tindakan penyidikan.

Adanya pengecualian yang diberikan oleh UUPM bagi perusahaan efek yang juga sebagai orang dalam, ${ }^{25}$ tidak menghalangi pelaksanaan penyidikan. justru dalam penyidikan yang dilakukan dapat dicari bukti-bukti yang diperlukan. Selain itu, pengecualian ini dapat disamakan dengan alasan pemaaf ataupun pembenar dalam hukum pidana, apabila dipersidangan terbukti bersalah akan tetapi ada alasan yang membebaskannya, maka dapat dilepaskan dari tuntutan oleh hakim. Akan tetapi untuk sampai kepersidangan, harus dilakukan penyidikan terlebih dahulu.

Sebagai bahan perbandingan tentang pelaksanaan pemeriksaan, dapat diberikan contoh lain yang juga terjadi yaitu kasus PT. Bank Mashill Tbk. Dalam kasus ini telah ditemukan beberapa pelanggaran terhadap UU No.8 Tahun 1995, termasuk praktik insider trading. Dalam analisis hukumnya pada tahap pemeriksaan oleh Bapepam, PT. Sumatra Central Prima sebagai insider Bank Mashill, dinyatakan bersalah telah melakukan praktik insider trading, hal ini didasarkan atas penjualan saham oleh pemegang saham utama Bank Mashill. Berdasarkan hal tersebut, maka Bapepam mengenakan sanksi administratif berupa denda Rp.500 juta kepada PT. Sumatera Central Prima, dan tidak meneruskan kasusnya kepenyidikan. ${ }^{26}$ Dari kasus tersebut, dimana keduanya merupakan tindak pidana, tindakan yang dilakukan Bapepam hanya sebatas pemeriksaan saja, walaupun salah satu dari kasus tersebut telah nyata-nyata dalam analisis hukumnya pada tingkat pemeriksaan dinyatakan terbukti bersalah.

${ }^{25}$ Indonesia, UUPM, Op. Cit., Pasal 98 menjelaskan bahwa: Perusahaan Efek yang memiliki informasi orang dalam mengenai Emiten atau Perusahaan Publik dilarang melakukan transaksi Efek Emiten atau Perusahaan Publik tersebut, kecuali apabila :

a. transaksi tersebut dilakukan bukan atas tanggungannya sendiri, tetapi atas perintah nasabahnya, dan;

b. Perusahaan Efek tersebut tidak memberikan rekomendasi kepada nasabahnya mengenai Efek yang bersangkutan.

26 Indra Safitri, "Bank Mashill vs Aliansi Tito" dalam Transparansi, Independensi, Dan Pengawasan Kejahatan Pasar Modal (Kajian Kasus Kontroversial Insider Trading, Hostile Take Over Dan Market Manipulation Di Bursa Saham), (Jakarta: Go Global Book (Book Publishing Division Safitri \& Co., 1998) hal. 247-263. 
Dengan tidak dilakukannya penyidikan terhadap kasus Bank Mashill tetapi hanya pemeriksaan saja, kemudian langsung menjatuhkan sanksi kepada pelaku pelanggaran termasuk pelanggaran pidana, maka Bapepam sebagai pemeriksa sekaligus mengambil alih peran penyidik, penuntut umum, maupun hakim hanya dalam satu tingkat pengusutan yaitu dalam pemeriksaan. Hal yang demikian adalah tidak fair, Bapepam memang diberikan kewenangan oleh UUPM untuk melakukan hal tersebut, tetapi hanya untuk pelanggaran yang sifatnya administratif, bukan termasuk kejahatan seperti insider trading, karena-Bapepam bukanlah lembaga peradilan yang dapat memutus suatu perkara pidana. Dalam hal terjadi tindak pidana atau kejahatan sesuai yang diatur oleh UUPM, seharusnya dilakukan penuntutan pidananya sesuai UUPM, dan penyidikan merupakan tindakan awal dari penuntutan.

Pelaksanaan kewenangan penyidikan oleh Bapepam baru terlihat pada tahun 1999, dari 10 kasus yang terjadi dan diperiksa oleh Bapepam, hanya 1 kasus yaitu kasus PT. Bank Bali Tbk. yang sangat menarik perhatian masyarakat nasional maupun International. Dalam kasus ini, Tim Penyidik Bapepam telah menyampaikan berkas perkaranya kepada Kejaksaan Agung pada tanggal 16 Desember 1999 terkait dengan tindak pidana pasar modal yang terjadi. ${ }^{27}$

Pada tahun 2006, Bapepam-LK telah melakukan Pemeriksaan sebagaimana dimaksud dalam pasal 100 UUPM, sebanyak 16 (enam belas) kasus. Dari enam belas kasus tersebut, sebanyak 10 (sepuluh) kasus masih dalam proses pemeriksaan. Sebanyak 6 (enam) kasus telah selesai diperiksa. Dari 6 (enam) kasus telah selesai diperiksa, 2 (dua) kasus diantaranya telah dikenakan sanski, baik sanksi administratif maupun perintah untuk melakukan tindakan tertentu kepada pihak-pihak yang melakukan pelanggaran, satu kasus ditutup karena tidak ditemukan adanya pelanggaran peraturan di bidang pasar modal, 2 (dua) kasus dalam proses pengenaan sanksi dan satu kasus ditingkatkan ke tahap penyidikan, karena adanya indikasi kuat terjadi tindak pidana di bidang pasar modal. ${ }^{28}$

hal. 26.

\footnotetext{
27 "Laporan Tahunan Bapepam Tentang Penegakan". Tahun 1999, hal. 5.

28 "Laporan Tahunan Bapepam-LK Tentang Penegakan Hukum". Tahun 2006,
} 
Pada tahun 2006 Bapepam-LK telah melakukan Penyidikan sebagaimana dimaksud dalam pasal 101 UUPM sebanyak 4 (empat) kasus, 2 (dua) kasus merupakan peningkatan dari proses pemeriksaan yang telah diselesaikan oleh Bapepam-LK, yaitu kasus PT. BNI Sekuritas dan kasus perdagangan saham PT. Sugi Samapersada Tbk. (SUGI) dan saham PT. Arona Binasejati Tbk. (ARTI). Sedangkan 2 (dua) kasus lainnya merupakan penyidikan langsung, yaitu kasus PT. Bank BNI Tbk. dan kasus auditor PT. Great River International Tbk. (GRIV) untuk LK 2003.

Bapepam-LK telah berhasil menyelesaikan penyidikan atas kasus yang menyangkut tindak pidana pasal 107 UUPM jo pasal 104 UUPM, yaitu yang terkait dengan dugaan manipulasi laporan keuangan PT. United Capital Indonesia Tbk. Hasil Penyidikan tersebut telah diserahkan ke Jaksa Penuntut Umum dan telah dinyatakan lengkap (P-21) dan telah ditindak-lanjuti dengan penyerahan tersangka dan barang bukti.

Akhir tahun 2006, Bapepam-LK juga telah melimpahkan berkas perkara atas 2 (dua) kasus ke pihak Kejaksaan Tinggi melalui Korwan PPNS, yaitu:

1. Kasus dugaan atas kegiatan Manajer Investasi tanpa izin yang dilakukan oleh PT. Jasabanda yang melanggar pasal 103 UUPM jo pasal 30 ayat (2) UUPM dan pasal 32 ayat (1) UUPM dengan tersangka RM, AH dan BLD dengan ancaman hukuman paling lama 5 (lima) tahun penjara dan denda paling banyak Rp. 5 Miliar;

2. Kasus overstatement atas penyajian akun dan piutang dalam Laporan Keuangan PT. Great River International Tbk. per 31 Desember 2003, serta penambahan aktiva tetap perseroan, khususnya yang terkait dengan penggunaan dana hasil emisi obligasi, yang tidak dapat dibuktikan kebenarannya yang diduga melanggar pasal 107 UUPM jo pasal 104 UUPM jo pasal 93 UUPM jo pasal $55 \mathrm{KUHP}$ dan pasal $56 \mathrm{KUHP}$, dengan tersangka ST dan kawan-kawan ancaman hukuman paling lama 10 (sepuluh) tahun penjara dan denda paling banyak sebesar Rp. 15 Miliar.

Diantara kasus-kasus yang sedang ditangani oleh BapepamLK, terdapat beberapa kasus yang cukup memperoleh perhatian publik. Pertama adalah redemption reksa dana secara besar- 
besaran yang mengakibatkan turunnya Nilai Aktiva Bersih (NAB) reksa dana yang dikelola oleh PT. BNI Sekuritas secara signigikan. Kasus kedua yang juga cukup memperoleh perhatian publik adalah kasus transaksi saham PT. Sugi Samapersada Tbk. (SUGI) dan PT. Arona Binasejati Tbk. (ARTI).

Dari data di atas, terlihat bahwa kewenangan penyidikan baru mulai dilakukan sejak tahun 1999, akan tetapi masih sangat terbatas bila dilihat dari jumlah kasus yang terjadi, padahal penyidikan itu sangat penting dan harus dilakukan bila terjadi tindak pidana. Secara umum, pelaksanaan kewenangan penyidikan oleh Bapepam masih jauh dari harapan, dan sampai saat inipun kasus yang disidik pada tahun 2007 belum ada penyelesaiannya.

\section{Penutup}

\section{A. Kesimpulan}

Berdasarkan uraian pada bab-bab sebelumnya, maka kesimpulannya adalah:

1. Indikator yang dapat dipergunakan untuk mengungkap insider trading, yaitu; return or negative return, volatility, frequency transaction, volume transaction, dominasi anggota bursa, maka otoritas pengawasan dan penegakan hukum di pasar modal, berdasarkan Undang-undang No. 8 Tahun 1995 Tentang Pasar Modal berada ditangan Bapepam-LK sebagai satu-satunya lembaga yang menjalankan peran tersebut untuk melakukan analisis. Hal ini dibuktikan dengan pemberian kewenangan untuk melakukan pemeriksaan dan atau penyidikan apabila menurutnya telah terjadi pelanggaran terhadap Undang-undang pasar modal. Dalam menjalankan peran sebagai pemegang otoritas pengawasan di pasar modal, Bapepam-LK telah melaksanakan fungsi pemeriksaan dengan sangat baik,

2. Terkait dengan kasus dugaan insider trading PT. Perusahaan Gas Negara (Persero) Tbk. berdasarkan pasal 95 UUPM seharusnya sudah dapat dilakukan penyidikan dimana unsur-unsurnya telah terpenuhi. Peranan Bursa Efek dalam hal terjadinya dugaan insider trading atau kejahatan lainnya di dalam pasar modal sangat menetukan, dimana dalam hal terdapat ketidak-wajaran yang terjadi pada perdagangan saham suatu emiten, maka sistim 
penolakan (auto rejection) dapat menditeksi ketidak wajaran yang terjadi. Dalam hal ini, seharusnya Bapepam-LK dan Bursa Efek dapat mengambil langkah-langkah konkrit untuk menanggulangi kejahatan yang terjadi di pasar modal. Adanya pengecualian oleh pasal 98, tidak menghalangi ataupun meniadakan penyidikan, justru penyidikan tetap harus dilakukan agar ditemukan bukti untuk penuntutannya. Sedangkan pemeriksaan dapat dilaksanakan tetapi hanya merupakan tindakan pendahuluan dari penyidikan, sebatas mencari bukti-bukti awal dan menemukan peristiwa pidananya. Bila Bapepam-LK tidak tegas menjalankan tugasnya, maka kejahatan di pasar modal khususnya insider trading akan terus berlanjut.

3. Pembuktian tindak pidana insider trading, memang cukup sulit, akan tetapi bukan tidak mungkin dibuktikan. Memang sangat dimungkinkan terjadi bahwa tidak terbukti tindak pidananya, akan tetapi yang penting adalah pelaksanaan penuntutannya telah dilakukan sesuai prosedur dan transparan serta tindakan tersebut diawali oleh pelaksanaan penyidikan, sehingga tidak menimbulkan kecurigaan seperti saat ini.

\section{B. Saran}

Berdasarkan rumusan dari kesimpulan diatas, maka saran dari penulis adalah sebagai berikut:

1. Peran Bapepam-LK dalam penegakan hukum pasar modal harus terus diupayakan, terutama yang menyangkut kasus-kasus pidana termasuk insider trading berdasarkan indikator-indikator yang telah ditentukan. Hal ini dapat diwujudkan dengan pemberian sanksi pidana bagi mereka yang terbukti bersalah. Ini sangat penting agar terdapat satu kata dalam diri para pejabat BapepamLK, sehingga terwujudnya kepastian hukum dapat terjadi.

2. Transparansi dalam pengusutannya perlu dijalankan, sehingga jangan ada lagi sikap mendua untuk melaksanakan penegakan hukum di pasar modal. Sikap tegas dari Bapepam-LK sangat perlu, agar para investor mendapatkan kepastian hukum, dan mereka dapat mempercayai bahwa Bapepam-LK dapat diandalkan sebagai lembaga yang mempunyai otoritas sebagai pengawas dan penegak hukum di pasar modal sesuai dengan yang diberikan oleh Undang-undang No. 8 Tahun 1995 Tentang Pasar Modal.

3. Terkait dengan pengecualian yang diberikan oleh pasal 98 UUPM, sebaiknya dilakukan pembuktian secara maksimal oleh Bapepam- 
LK seperti, melihat track record dari nasabah tersebut dalam melakukan investasinya di pasar modal selama ini. Apakah mereka sering akurat membuat prediksi atas keadaan suatu emiten dan volume transaksinya cukup besar, atau apakah memang nasabah tersebut sering bertransaksi atas saham PT. Perusahaan Gas Negara (Persero) Tbk. Bapepam-LK harus bekerja keras untuk dapat membuktikannya, akan tetapi bukan berarti kasus insider trading tidak dapat dibuktikan. 


\section{Daftar Pustaka}

Djalil, Sofyan A., Manipulation and Insider Trading, (Jakarta: Makalah disampaikan dalam Pendidikan dan Latihan Modul Capital Market Studies Program (CMSP) Bagi Profesi Penunjang Untuk Konsultan Hukum Pasar Modal, oleh Lembaga Manajemen Keuangan dan Akuntasi (LMKA) bekerja sama dengan Himpunan Konsultan Hukum Pasar Modal (HKHPM) Angkatan VI, 10-28 Juni 1996),

Fuady, Munir. Pasar Modal Modern (Tinjauan Hukum), (Bandung:PT. Citra Aditya Bakti, 1996)

Indonesia, Undang-Undang Tentang Pasar Modal, UU No. 8, LN No. 64 Tahun 1995, TLN No. 3608

Laporan Tahunan Bapepam Tentang Penegakan, Tahun 1999

Laporan Tahunan Bapepam-LK Tentang Penegakan Hukum, Tahun 2006,

Nasarudin, M. Irsan, dan Indra Surya, M. Irsan Nasarudin dan Indra Surya, Aspek Hukum Pasar Modal Indonesia, (Jakarta: Prenada Media, 2004), Sekapur Sirih,

Nefi, Arman. "Return, Volatilitas, Nilai Transaksi, dan Dominasi Anggota Bursa Di Seputar Dugaan Insider Trading", (Tesis Magister Manajemen Fakultas Ekonomi, Universitas Indonesia, Depok, 2005).

P. Friedman. Dictionary of Business Terms, New York, USA: Baron's Educational Series, Inc., 1987.

Safitri, Indra. Kejahatan Di Pasar Modal, Jakarta: Go Global Book Publishing Division Safitri \& Co, 1998.

Soekanto, Soerjono, dan Sri Mamuji. Penelitian Hukum Normatif, Cet.4, Jakarta: PT. Raja Grafindo Persada, 1994.

"Bank Mashill vs Aliansi Tito" dalam Transparansi, Independensi, Dan Pengawasan Kejahatan Pasar Modal (Kajian Kasus Kontroversial Insider Trading,Hostile Take Over Dan Market Manipulation Di Bursa Saham), (Jakarta: Go Global Book (Book Publishing Division Safitri \& Co., 1998).

"Tiga Perusahaan Sekuritas Divestasi PGN", Pikiran Rakyat (23 Oktober 2006). 
"Bapepam: Pelaku Kasus PGN Mengarah ke Perseorangan", <http://www.tempointeraktif.com/hg/ekbis/2007/02/05/brk,2007 0220-93778,id.html>, diakses tanggal 15 Maret 2007.

"Transaksi Saham PGN di Stop", <http://www.detikfinance.com/ index.php/>, diakses tanggal 15 Maret 2007. 